\title{
Steel slag quality control for road construction aggregates and its environmental impact: Case study of Vietnamese steel industry - Leaching of heavy metals from steel making slag
}

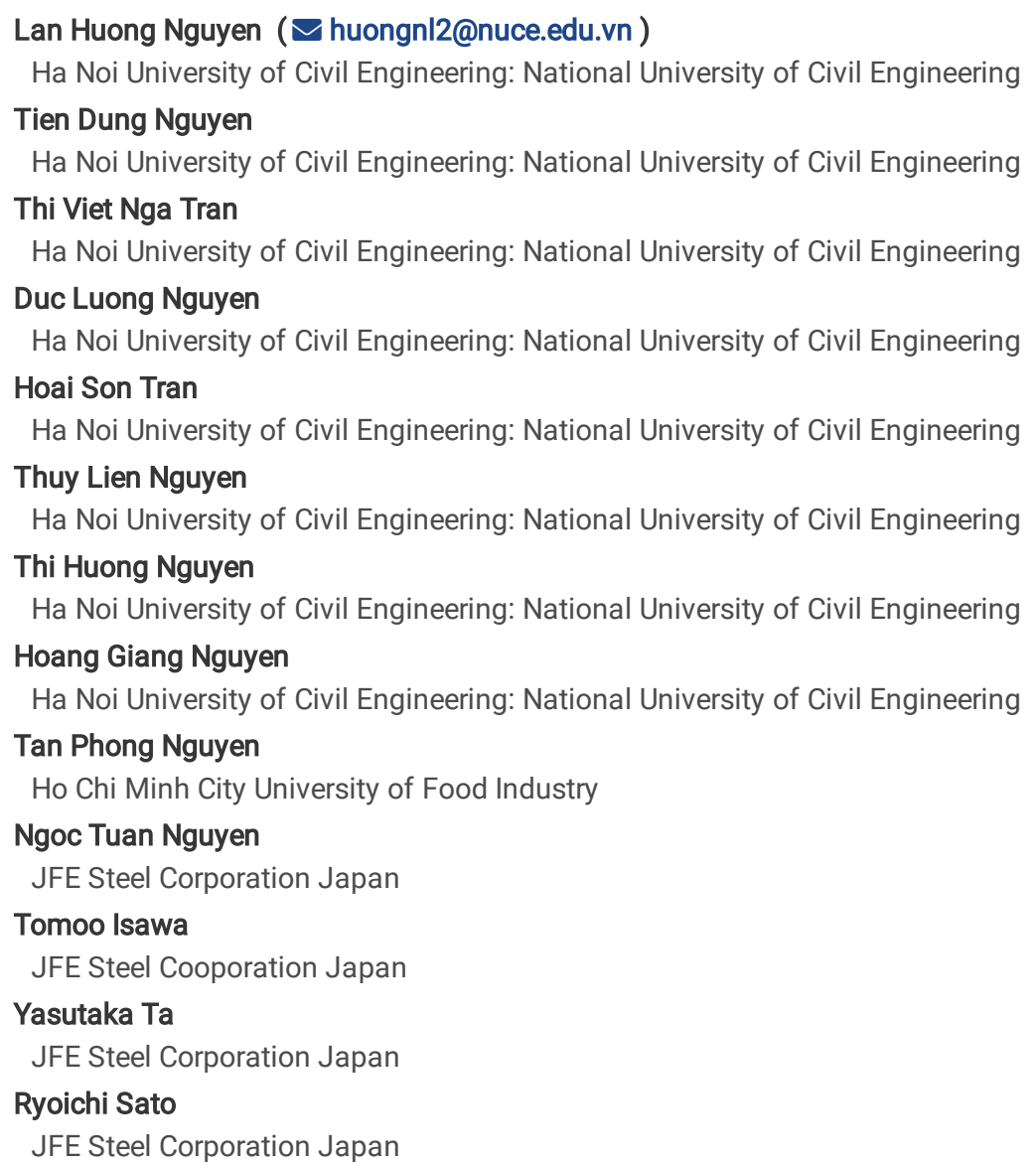

Research Article

Keywords: steel making slag, leaching test, industry by-product, environmental impact, quality control, JIS K 0058-1, EPA method 1311

Posted Date: April 19th, 2021

DOI: https://doi.org/10.21203/rs.3.rs-342976/v1

License: (c) (i) This work is licensed under a Creative Commons Attribution 4.0 International License. Read Full License 


\section{Abstract}

Steel slag is an industrial by product of steel manufacturing processes and has been widely used in countries like Japan, United States, and European Union nations. However, the current utilization of steel slag in Vietnam is very low mainly because of lack of quality control of slag treatment and chances for reuse of treated steel slag. This paper presents the current steel slag production status and its potential to use as road construction aggregates in consideration of environmental and quality control issues. The basic oxygen furnace (BOF) and electric arc furnace (EAF) slag samples were collected from the seven large steel making factories of Vietnam and brought back to evaluate leaching amount from the slags. The batch leaching test methods were performed at laboratory using the leaching test of steel slag roadbed material in Japan (JIS K $0058-1$ ) and Toxicity Characteristic Leaching Procedure (EPA method 1311) widely adopted in Vietnam. The results show that pH level and parameters such as $\mathrm{T}-\mathrm{Cr}$, $\mathrm{Ni}$, $\mathrm{Cu}$, $\mathrm{Pb}, \mathrm{As}, \mathrm{Mn}$ differ from the two test methods. The EPA 1311 seems too harsh to evaluate the environmental impacts because in the operation condition of the road, acidic liquid is absent. It is concluded that JIS test, which uses fresh water with gentle mixing not to degradation in size while leaching, is suitable for the evaluation, for the environmental assessment in service of the slag aggregate for roadbed.

\section{Introduction}

Steel slag is an industrial by product of steel making processes and has been widely used in countries like Japan, United States, and European Union nations. Steel slag has been widely utilized as construction materials for road construction and environmental remediation because of its similarity in physical properties as natural materials such as gravel (Chen et al. 2020; Hainin et al. 2015; Horii et al. 2013; Liyun et al. 2017; Mombelli et al. 2016; Piatak et al. 2015).

According to the Steel Industry Report (2019), the steel making industry in Vietnam is the fast-growing industry with the growth rate of $17 \%$ per year from 2014 to 2018 and forecast a 9\% growth from 2019 to 2023. Together with the increase of steel products, the amount of slag generated in 2018 is about 4.2 million ton. While there is increasing demand for utilizing steel slag for road construction in Vietnam, due to the lack of national regulations and guidelines, most of the slag remains unutilized and kept in the storage yard in the factory area. On the other hand, there is also the concern about bulk utilization of steel slag may post the significant impact to the environment due to leaching of hazardous substances from steel slag matrix, which may become mobile in ground water and soil environment (Chaurand et al. 2007; Riley and Mayes 2015; Spanka et al. 2018). Because slag is widely re-used as construction materials and environmental application globally, the assessment of environmental aspects of slag would contribute to encourage the utilization of steel slag in Vietnam.

This paper presents the current steel slag production status and its potential to use as road construction aggregates in consideration of environmental and quality control issues. The BOF, EAF and IF slag samples were collected from the seven steel making factories in Vietnam with relatively high crude steel production to evaluate leaching amount from the slags. The leaching test methods were compared using the leaching test of steel slag roadbed material in Japan (JIS K 0058 - 1) and EPA method 1311 widely adopted in Vietnam.

According to statistics of the Vietnam Steel Association (VSA), in Vietnam, there are more than 70 factories producing crude and finished steel. In 2020, crude steel production is estimated at 18 million tons. Vietnam steel market will become one of the fastest growing markets in the world from 2020 to 2024. The slag volume of the iron and steel industry is expected to reach 7.1 million tons by 2020 .

Steel slag is generated from the steel production process. Depending on the type of the furnace, the steel slag is characterized into two types: Basic Oxygen Furnace Slag - BOF and Electric Arc Furnace slag - EAF.

Basic Oxygen Furnace slag is generated during refining of hot metal produced at blast furnaces, into steel in BOF. While carbon in iron is eliminated as gaseous carbon monoxide by injected oxygen, the impurities like silicon, manganese phosphorus and iron are also oxidized to form liquid state slag with lime and dolomite; the mixture of these oxides phase are called slag. Due to the difference in density with molten steel, liquid slag will float to the top and be removed from the furnace to form the steel slag after cooling. BOF slag is slowly cooled by natural air, or sprays water at the cooling yard. The yield of BOF slag is about $100-150 \mathrm{~kg}$ per ton of molten steel.

Electric arc furnaces use graphite electrodes to increase the temperature to melt by arcing and refining raw materials (scrap steel, lump cast iron). Some other metals like ferro, alloys are added to balance the required chemical compositions of steel, and oxygen is also used for refining of molten steel. Oxidizing slag and Reducing slag (reduction process) are generated from each stage of the steel making process. The yield of Oxidizing slag and Reducing slag is $100 \mathrm{~kg}$ and $50 \mathrm{~kg}$ per ton of molten steel respectively. The manufacturing of steel slag was illustrated in Fig. 1. Most of the steel slag produced is then dumped in the steel plant areas while hot and cooled in the slag storage yards. In some factories, slag was processed by sieving and magnetic separation for metal recovery

\section{Materials And Methods}

\section{Steel slag collection and pre-treatment}

The BOF and EAF slag samples were collected from seven dumping sites of the steel plants during May 2019. The slags were stored in plastic containers and transported back to the laboratory for analysis. At the laboratory, the coarse particles were crushed and sieved to meet TCVN 
8857:2011 - Natural aggregate for road pavement layers - Specification for material, construction, and acceptance Type C (Table 1). Although the type $\mathrm{C}$ consists of fine and coarse particles, the particles of $10 \mathrm{~mm}$ or more are eliminated for the leaching test; use of large particles means large vessel and equipment, and large sample volume, even though the contribution to leaching test is relatively low due to low specific surface area. In order to match the actual environment as close as possible (carbonation treatment) of steel slag, we put the $100 \mathrm{~g}$ slag into the container at room temperature and add $7 \mathrm{~g}$ of water by spraying. After one week, we add another $7 \mathrm{~g}$ of water and start the leaching procedure (Fig. 2).

Table 1

Particle range before crushing for leaching test (\%)

\begin{tabular}{|lllllll|}
\hline Sieve $(\mathbf{m m})$ & $\mathbf{2 5}$ & $\mathbf{9 . 5}$ & $\mathbf{4 . 7 5}$ & $\mathbf{2}$ & $\mathbf{0 . 4 2 5}$ & $\mathbf{0 . 0 7 5}$ \\
\hline Sample (\%) & & & & & & \\
\hline - Separate & 32.5 & 17.5 & 12.5 & 15 & 12.5 & 10 \\
\hline - Accumulate & 100 & 67.5 & 50.0 & 37.5 & 22.5 & 10 \\
\hline Type C (\%) & 100 & $50-85$ & $35-65$ & $25-50$ & $15-30$ & $5-15$ \\
(Requirement) & & & & & & \\
\hline
\end{tabular}

\section{Experimental procedure}

To investigate the mobility of trace metals in steel slags, the two type of single batch test were performed according to the US-EPA 1311 which is an evaluation method of waste and JIS K 0058 - 1 which is a standard for evaluating the environmental safety quality of steelmaking slag road base material in Japan (Table 2). The EPA 1311 standard procedure uses dilute acidic leachant solutions (acetic acid or acetate buffer) with a contact time of 18 hours and continuous end-over-end rotation of $30 \mathrm{rpm}$. While the JIS K $0058-1$ uses deionized water with a contact time of 6 hours and constant stirring frequency of $200 \mathrm{rpm}$. The $\mathrm{pH}$ and leached concentrations of trace element such as $\mathrm{Pb}, \mathrm{Hg}, \mathrm{Se}, \mathrm{As}, \mathrm{Cd}, \mathrm{T}-\mathrm{Cr}(\mathrm{Cr} 3+, \mathrm{Cr} 6+)$, Cr6 $+\mathrm{F}, \mathrm{B}$, $\mathrm{Mn}, \mathrm{Ni}, \mathrm{Zn}, \mathrm{Cu}, \mathrm{F}, \mathrm{B}$ were measured by $\mathrm{pH}$ meter and ICP-OES. The detection limit of ICP-OES for Pb, $\mathrm{Hg}, \mathrm{Se}, \mathrm{As}, \mathrm{Cd}, \mathrm{T}-\mathrm{Cr}(\mathrm{Cr} 3+, \mathrm{Cr} 6+), \mathrm{Cr} 6+, \mathrm{F}, \mathrm{B}, \mathrm{Mn}, \mathrm{Ni}$, $\mathrm{Zn}$, Cu was $0.005,0.005,0.002,0.005,0.001,0.01,0.02,0.08,0.1,0.01,0.1,0.1 \mathrm{mg} / \mathrm{L}$ respectively.

Table 2

Extraction method for leaching tests

\begin{tabular}{|llllllll|}
\hline & Equipment & Frequency & Duration & Sample size & Weight & Leachant & L/S ratio (L/kg) \\
\hline JIS K 0058-1 & Mixing blade & $200 \mathrm{rpm}$ & $6 \mathrm{hrs}$ & $<2 \mathrm{~mm}$ & $500 \mathrm{~g}$ & Deionized water & 10 \\
\hline EPA 1311 & End over end rotation & $30 \mathrm{rpm}$ & $18 \mathrm{hrs}$ & $<10 \mathrm{~mm}$ & $100 \mathrm{~g}$ & Acetic acid & 20 \\
\hline
\end{tabular}

\section{Results And Discussion}

The $\mathrm{pH}$ level and element leachate concentration in steel slag sample were given in Table 3. It is noticed that the $\mathrm{pH}$ and alkalinity of the leachate from JIS K 0058 - 1 test were significantly higher than those from EPA 1311 test. The reason is that JIS standard uses deionized water while EPA test employ acetic acid for leachant. The leached $\mathrm{pH}$ in most samples is higher than the National Technical Regulation on Industrial Wastewater (QCVN 40:2011/BTNMT). The high alkaline level was also found in other studies, because of the dissolution of Ca silicates, oxides, and/or carbonates to form Ca2 + ion and hydroxyl OH- (Chand et al. 2019; Piatak et al. 2015). 
Table 3

Chemical characteristics and min/max element leachate concentration in steel slag samples (bold numbers indicate over Vietnamese standard for industrial wastewater discharge - QCVN 40-2011)

\begin{tabular}{|c|c|c|c|c|c|c|c|c|c|c|c|c|c|c|c|c|}
\hline & \multicolumn{2}{|c|}{ Parameters } & $\mathrm{pH}$ & $\mathrm{Pb}$ & $\mathrm{Mn}$ & $\mathrm{Hg}$ & $\mathrm{Ni}$ & $\mathrm{Se}$ & $\mathrm{Zn}$ & As & Cd & $\mathrm{T}-\mathrm{Cr}$ & $\mathrm{Cr}^{6+}$ & $\mathrm{Cu}$ & $\mathbf{F}$ & B \\
\hline \multicolumn{3}{|c|}{ QCVN 40-2011 } & $6-9$ & 0.1 & 0.5 & 0.01 & 0.2 & 0.01 & 3 & 0.05 & 0.05 & 0.2 & 0.05 & 2 & 5 & \\
\hline \multicolumn{3}{|c|}{ Sample ID } & - & $\mathrm{mg} / \mathrm{L}$ & $\mathrm{mg} / \mathrm{L}$ & $\mathrm{mg} / \mathrm{L}$ & $\mathrm{mg} / \mathrm{L}$ & $\mathrm{mg} / \mathrm{L}$ & $\mathrm{mg} / \mathrm{L}$ & $\mathrm{mg} / \mathrm{L}$ & $\mathrm{mg} / \mathrm{L}$ & $\mathrm{mg} / \mathrm{L}$ & $\mathrm{mg} / \mathrm{L}$ & $\mathrm{mg} / \mathrm{L}$ & $\mathrm{mg} / \mathrm{L}$ & $\mathrm{mg} / \mathrm{L}$ \\
\hline \multirow{4}{*}{$\begin{array}{l}1- \\
\text { EAF }\end{array}$} & \multirow{2}{*}{$\begin{array}{l}\text { EPA } \\
1311\end{array}$} & Min & 6.1 & - & 96.8 & - & 0.09 & - & 1.10 & 0.01 & - & - & - & - & 0.63 & 0.62 \\
\hline & & Max & 6.5 & 0.01 & 120.0 & 0.004 & 0.14 & - & 1.59 & 0.01 & - & 0.04 & - & - & 0.99 & 0.71 \\
\hline & \multirow{2}{*}{$\begin{array}{l}\text { JIS K } \\
0058 \\
-1\end{array}$} & Min & 9.9 & - & - & - & - & - & - & - & - & - & - & - & 0.83 & - \\
\hline & & Max & 10.2 & - & - & - & - & - & - & - & - & - & - & - & 1.02 & - \\
\hline \multirow{4}{*}{$\begin{array}{l}2- \\
\text { BOF }\end{array}$} & \multirow{2}{*}{$\begin{array}{l}\text { EPA } \\
1311\end{array}$} & Min & 12.1 & - & - & - & - & - & - & - & - & - & - & - & 0.41 & 0.25 \\
\hline & & Max & 12.4 & - & - & - & - & - & - & - & - & - & - & - & 0.44 & 0.37 \\
\hline & \multirow{2}{*}{$\begin{array}{l}\text { JIS K } \\
0058 \\
-1\end{array}$} & Min & 12.3 & - & - & - & - & - & - & - & - & 0.01 & - & - & 0.15 & 0.11 \\
\hline & & Max & 12.4 & - & - & - & - & - & - & - & - & 0.02 & - & - & 0.19 & 0.11 \\
\hline \multirow[t]{4}{*}{ 3-IF } & \multirow{2}{*}{$\begin{array}{l}\text { EPA } \\
1311\end{array}$} & Min & 3.7 & 0.06 & 17.20 & - & 0.15 & - & 2.72 & - & 0.003 & 0.20 & - & 0.16 & 0.85 & 1.42 \\
\hline & & Max & 3.8 & 0.09 & 20.10 & - & 0.18 & - & 3.75 & - & 0.004 & 0.31 & - & 0.39 & 1.09 & 1.83 \\
\hline & \multirow{2}{*}{$\begin{array}{l}\text { JIS K } \\
0058 \\
-1\end{array}$} & Min & 8.4 & - & 0.14 & - & - & - & - & - & - & - & - & - & 0.11 & 0.41 \\
\hline & & Max & 8.7 & - & 0.16 & - & - & - & - & - & - & - & - & - & 0.15 & 0.57 \\
\hline \multirow{4}{*}{$\begin{array}{l}\text { 4- } \\
\text { BOF }\end{array}$} & \multirow{2}{*}{$\begin{array}{l}\text { EPA } \\
1311\end{array}$} & Min & 7.5 & - & 1.84 & - & 0.01 & - & 0.12 & - & - & - & - & - & 4.95 & 0.79 \\
\hline & & Max & 7.9 & - & 5.77 & - & 0.02 & - & 0.32 & - & - & - & - & - & 9.70 & 0.90 \\
\hline & \multirow{2}{*}{$\begin{array}{l}\text { JIS K } \\
0058 \\
-1\end{array}$} & Min & 9.6 & - & - & - & - & - & - & - & - & - & - & - & 1.57 & 0.28 \\
\hline & & Max & 9.7 & - & - & - & - & - & - & - & - & - & - & - & 1.97 & 0.33 \\
\hline \multirow{4}{*}{$\begin{array}{l}\text { 5- } \\
\text { EAF }\end{array}$} & \multirow{2}{*}{$\begin{array}{l}\text { EPA } \\
1311\end{array}$} & Min & 7.1 & 0.01 & 2.50 & - & - & - & - & - & - & - & - & - & 0.08 & 0.27 \\
\hline & & Max & 7.2 & 0.01 & 2.63 & - & - & - & - & - & - & - & - & - & 0.10 & 0.28 \\
\hline & \multirow{2}{*}{$\begin{array}{l}\text { JIS K } \\
0058 \\
-1\end{array}$} & Min & 10.9 & - & - & - & - & - & - & - & - & - & - & - & - & - \\
\hline & & Max & 11.1 & - & - & - & - & - & - & - & - & - & - & - & - & - \\
\hline \multirow{4}{*}{$\begin{array}{l}\text { 6- } \\
\text { EAF }\end{array}$} & \multirow{2}{*}{$\begin{array}{l}\text { EPA } \\
1311\end{array}$} & Min & 7.6 & - & 1.27 & - & 0.01 & - & 0.12 & 0.01 & 0.002 & - & - & - & 7.44 & 2.84 \\
\hline & & Max & 8.5 & - & 6.42 & - & 0.04 & - & 0.12 & 0.01 & 0.002 & - & - & - & 8.90 & 4.04 \\
\hline & \multirow{2}{*}{$\begin{array}{l}\text { JIS K } \\
0058 \\
-1\end{array}$} & Min & 9.8 & - & - & - & - & 0.003 & - & - & - & - & - & - & 1.25 & 1.74 \\
\hline & & Max & 10.6 & - & - & - & - & 0.004 & - & - & - & - & - & - & 3.39 & 5.23 \\
\hline \multirow{4}{*}{$\begin{array}{l}7- \\
\text { EAF }\end{array}$} & \multirow{2}{*}{$\begin{array}{l}\text { EPA } \\
1311\end{array}$} & Min & 4.2 & 0.04 & 88.0 & - & 0.25 & - & 0.77 & 0.01 & 0.002 & 0.06 & - & 0.40 & 1.31 & 0.69 \\
\hline & & Max & 4.3 & 0.20 & 130.0 & - & 0.28 & - & 1.40 & 0.01 & 0.004 & 0.07 & - & 0.74 & 1.61 & 0.95 \\
\hline & \multirow{2}{*}{$\begin{array}{l}\text { JIS K } \\
0058 \\
-1\end{array}$} & Min & 9.3 & - & - & - & - & - & - & - & - & - & - & - & 0.11 & - \\
\hline & & Max & 10.0 & - & - & - & - & - & - & - & - & - & - & - & 0.13 & - \\
\hline
\end{tabular}

The $\mathrm{pH}$ level is a major parameter controlling the leaching of many elements in slags and shown clearly from the results of the two different leaching procedures employed. The standard leaching tests EPA results shows that some hazardous element was leached from the samples with the amount may be harmful to the environment such as $\mathrm{F}, \mathrm{Pb}, \mathrm{As}, \mathrm{Hg}, \mathrm{Cd}, \mathrm{Mn}, \mathrm{Ni}, \mathrm{T}$. Cr and $\mathrm{B}$. The release of trace metals was likely because of lower pH of the buffer solution and enhanced extraction by acetic acid (Ettler et al. 2009; Proctor et al. 2000). The concentration of the leached element from EPA 1311 procedure was significantly higher than that from JIS K 0058 - 1 procedure, especially for Mn, T. Cr and F (Table 3, Fig. 3). Most of the concentration of toxic elements in leachate results from JIS K 0058-1 method were lower than detection limit of the ICP-OES and far below the standard for industrial wastewater discharge (QCVN 40-2011/BTNMT). These results are identical to those of the studies by Liyun et al. (2017) and Oh et al. (2012). $\operatorname{Cr}(6+)$ was not detected by either method. 
The particle size of slag and liquid to solid ratio also affect the leaching of metals during leaching tests (Chand et al. 2019; Liyun et al. 2017; Mizutani et al. 2006; Piatak et al. 2015; Riboldi et al. 2020). During the EPA 1311 test, the end-over-end rotation produces finer particles then compared to the agitation in the JIS K $0058-1$ test which accelerate the release of toxic elements to the leachant. While the increasing of water or leachant volume may increase the amount of dissolved slag and increase the leached concentration of trace metals.

\section{Conclusions}

For a better understanding of the status quo of Vietnamese steelmaking slag when applied to road building material, several steelmaking slags were collected from seven steel making factories in the region of Ha Noi, Da Nang and Ho Chi Minh city. The steel slags were crushed and sieved to meet the size distribution for road aggregate. Two types of single batch leaching test were performed according to the US-EPA 1311 and JIS K 0058 - 1 to analyze the possible environmental impact of the leached elements from slag when applying as roadbed aggregates. Some remarks can be obtained from the results of leaching tests:

- - The $\mathrm{pH}$ level is a major parameter controlling the leaching of many elements in slags and shown clearly from the results of the two different leaching procedures employed. The EPA 1311 seems too harsh to evaluate the environmental impacts when applied to slag aggregate because it is the method used for proper waste management;

- - The concentration of the leached element from EPA 1311 procedure was significantly higher than that from JIS K 0058 - 1 procedure, especially for Mn, T-Cr and F. Most of the concentration of hazardous element in leachate result from JIS K $0058-1$ method were lower than detection limit of the ICP-OES and far below the standard for industrial wastewater discharge (QCVN 40-2011/BTNMT). The results of the leaching test would suggest the possibility of safe utilizing slag for roadbed construction. Because of the correlation between chemical composition and leaching test results, it is suggested that to control a correct balance of chemical composition during the production of steel to generate stable and safe slag.

- - The particle size of slag and liquid to solid ratio are among the fundamental factors influencing the leaching of metals during leaching tests. It is suggested that a non-acidic, neutral or possibly alkali water that imitates groundwater or rainwater, and a gentle agitation without reduction in particle sizes, are suitable for the assessment of slag aggregates when used for road building such as JIS K 0058 - 1 procedure.

- - Some of Vietnamese steel making slag that meets the requirement of leached heavy metals is safely applicable to road aggregate for the conservation of natural resources. The criteria need to be promulgate by the Government such as the official guideline or standard to promote recursive use of by-product as long as it is safe in construction and in service; if not, those shall be disposed complying with the regulations of Vietnam.

\section{Abbreviations}

BOF: Basic Oxygen Furnace

EAF: Electric Arc Furnace

IF: Induction Furnace

\section{Declarations}

Ethics approval and consent to participate: Not applicable

\section{Consent for publication: Not applicable}

Availability of data and materials: the data presented in this study are available on request from the corresponding author. The data are not publicly available due to the information security conditions of the project.

Competing interests: The authors declare that they have no competing interests

Funding: This research is funded by National University of Civil Engineering (NUCE) under grant number 12 - 2021/KHXD-TĐ. The authors also gratefully acknowledge the support from JFE-Steel Corporation Japan, and Ho Chi Minh City University of Food Industry, Viet Nam.

Authors' contributions: LHN, YT, TLN analysed and interpreted the data regarding the leaching test. TDN, LHN, TPN, DLN, YT, TI, NTN performed field study and sampling. LHN was a major contributor in writing the manuscript. YT, TI, TVNT, THN, TPN, RS, HST, NTN, TLN, HGN contributed in writingreview and editing the manuscript. All authors read and approved the final manuscript

\section{References}

Chand S, Chand SK, Paul B, Kumar M (2019) Long-term leaching assessment of constituent elements from Linz-Donawitz slag of major steel industries in India International Journal of Environmental Science and Technology 16:6397-6404 doi:10.1007/s13762-018-2025-z

Page $5 / 8$ 
Chaurand P et al. (2007) Environmental impacts of steel slag reused in road construction: A crystallographic and molecular (XANES) approach Journal of Hazardous Materials 139:537-542 doi:https://doi.org/10.1016/j.jhazmat.2006.02.060

Chen $\mathrm{X}$ et al. (2020) Optimal regulation of N/P in horizontal sub-surface flow constructed wetland through quantitative phosphorus removal by steel slag fed Environmental Science and Pollution Research 27:5779-5787 doi:10.1007/s11356-019-06696-5

Ettler V, Johan Z, Kříbek B, Šebek O, Mihaljevič M (2009) Mineralogy and environmental stability of slags from the Tsumeb smelter, Namibia Applied Geochemistry 24:1-15 doi:https://doi.org/10.1016/j.apgeochem.2008.10.003

Hainin MR, A. Aziz MM, Ali Z, Putra Jaya R, Elsergany M, Yaacob H (2015) Steel Slag as A Road Construction Material doi:10.11113/jt.v73.4282

Horii K, Tsutsumi N, Kitano Y, Kato T (2013) Processing and reusing technologies for steelmaking slag Nippon Steel Technical Report:123-129

Liyun Y, Ping X, Maomao Y, Hao B (2017) The characteristics of steel slag and the effect of its application as a soil additive on the removal of nitrate from aqueous solution Environmental Science and Pollution Research 24:4882-4893 doi:10.1007/s11356-016-8171-2

Mizutani S, Watanabe N, Sakai S-I, Takatsuki H (2006) Influence of particle size preparation of MSW incineration residues on heavy metal leaching behavior in leaching tests Environmental sciences : an international journal of environmental physiology and toxicology 13:363-370

Mombelli D, Mapelli C, Barella S, Di Cecca C, Le Saout G, Garcia-Diaz E (2016) The effect of chemical composition on the leaching behaviour of electric arc furnace (EAF) carbon steel slag during a standard leaching test Journal of Environmental Chemical Engineering 4:1050-1060 doi:https://doi.org/10.1016/j.jece.2015.09.018

Oh C, Rhee S, Oh M, Park J (2012) Removal characteristics of As(III) and As(V) from acidic aqueous solution by steel making slag Journal of Hazardous Materials 213-214:147-155 doi:https://doi.org/10.1016/j.jhazmat.2012.01.074

Piatak NM, Parsons MB, Seal RR (2015) Characteristics and environmental aspects of slag: A review Applied Geochemistry 57:236-266 doi:https://doi.org/10.1016/j.apgeochem.2014.04.009

Proctor DM et al. (2000) Physical and Chemical Characteristics of Blast Furnace, Basic Oxygen Furnace, and Electric Arc Furnace Steel Industry Slags Environmental Science \& Technology 34:1576-1582 doi:10.1021/es9906002

Riboldi A et al. (2020) Grain Size Effect in Elution Test of Electric Arc Furnace Slag Applied Sciences 10 doi:10.3390/app10020477

Riley AL, Mayes WM (2015) Long-term evolution of highly alkaline steel slag drainage waters Environmental Monitoring and Assessment 187:463 doi:10.1007/s10661-015-4693-1

Securities V (2019) Vietnam Steel Industry Report.

Spanka M, Mansfeldt T, Bialucha R (2018) Sequential extraction of chromium, molybdenum, and vanadium in basic oxygen furnace slags Environmental Science and Pollution Research 25:23082-23090 doi:10.1007/s11356-018-2361-z

\section{Figures}




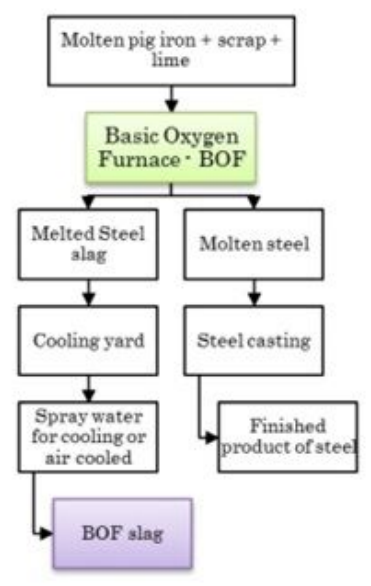

(a)

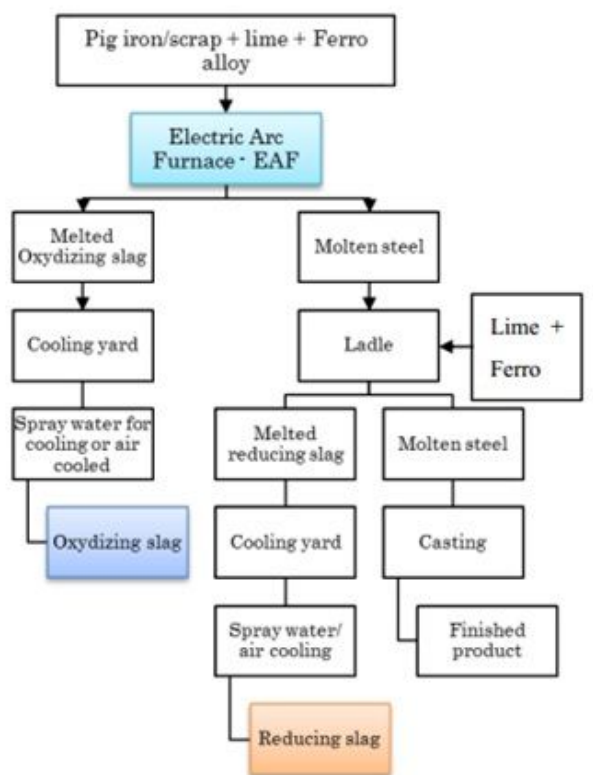

(b)

\section{Figure 1}

Schematic process of BOF steel slag (a) and EAF steel slag (b)

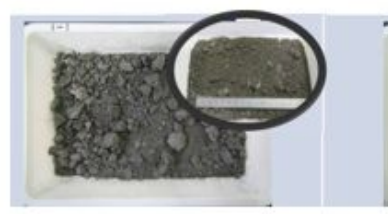

1- $\mathrm{EAF}$

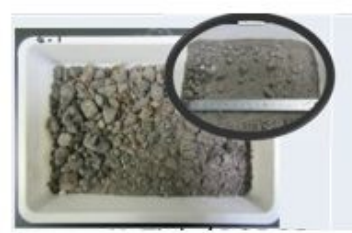

4- BOF

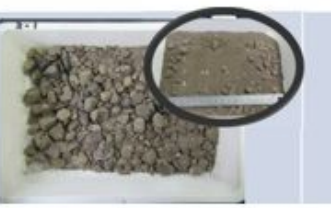

2- $\mathrm{BF} / \mathrm{BOF}$

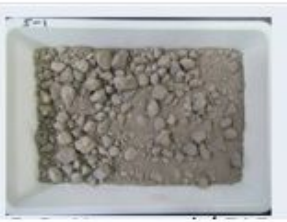

5- EAF

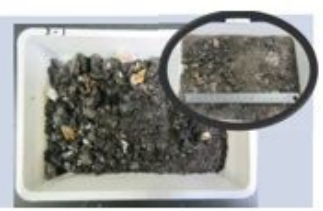

3-IF

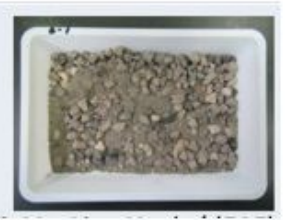

6- EAF

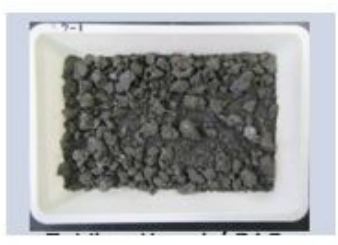

7- EAF

\section{Figure 2}

Slag samples after aging and crushing 

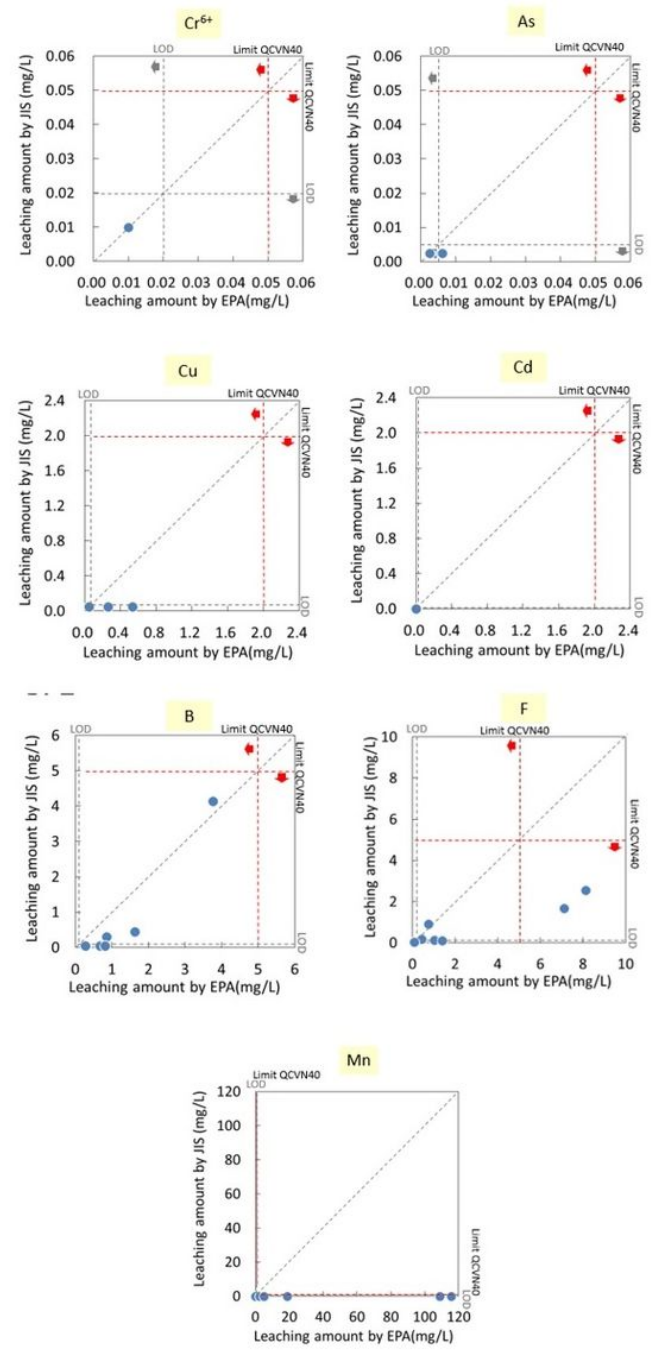

Figure 3

Chemistry of slag leachate from EPA 1311 and JIS 0058-1 